\title{
PENGARUH CORPORATE GOVERNANCE PERCEPTION INDEX, RISIKO, DAN KARAKTERISTIK PERUSAHAAN TERHADAP KINERJA KEUANGAN (STUDI EMPIRIS PERUSAHAAN GO PUBLIC DI CGPI)
}

\author{
Okajaya Kusuma Warenda \\ Triyono \\ Univesrsitas Muhammadiyah Surakarta \\ e-mail: okajaya.akt48
}

\begin{abstract}
This study examines the relationship between the corporate governance perception index, risk, and and firm characteristics that proxies by institutional ownership, growth opportunities (sales growth) and size on the firm's financial performance measured using return on equity (ROE). The method to analys this study is regression. Data which used is the data from 2006-2012 for 86 companies was listed Indonesia Stock Exchange (IDX) and included in the ranking of The Indonesian Institute for Corporate Governance ( IICG). The results indicates that corporate governance perception index, risk and growth opportunities (sales growth) have relationship with the firm 's financial performance. But, there is variable institusional ownership and size hasn't relationship with the firm's performance.

Keywords: corporate governance perception index, institusional ownership, sales growth, size of the firm, return on equity
\end{abstract}

\section{PENDAHULUAN}

Lemahnya corporate governance sering disebut sebagai salah satu penyebab krisis keuangan di negara-negara Asia. Darmawati et al (2004) di dalam penelitiannya, mengatakan bahwa variabel corporate governance yang diterapkan dalam suatu negara lebih mampu menjelaskan luasnya depresiasi mata uang dan menurunnya kinerja pasar modal di negaranegara berkembang dibandingkan variabelvariabel makro-ekonomika pada periode krisis. Ciri utama dari lemahnya corporate governance adalah adanya tindakan mementingkan diri sendiri dan mengabaikan kepentingan pemegang saham . Hal itu menyebabkan jatuhnya harapan para investor tentang pengembalian (returns) atas investasi yang telah mereka tanamkan sehingga
\end{abstract}

harga saham dan pasar modal tidak berkembang. (Nuswandari, 2009)

Menurut Meythi dan Devita (2011) Indonesia pada tahun 1997-1998 ( saat terjadi krisis ) mengalami kondisi dimana banyaknya perusahaan yang tidak mampu bertahan karena pertumbuhan ekonomi yang dicapai tidak dibangun diatas landasan yang kokoh sesuai dengan prinsip pengelolaan yang sehat. Jika corporate governance merupakan faktor yang signifikan pada kondisi krisis, maka corporate governance tidak hanya mampu menjelaskan perbedaan kinerja antar negara selama periode krisis, akan tetapi juga perbedaan corporate governance di tingkat perusahaan yang pada kenyataannya masih sangat sedikit dilakukan.

Di negara sedang berkembang seperti Indonesia masalah keagenan masih memiliki 
dimensi berbeda karena tidak hanya fokus pada kepemilikan dan manajemen, tetapi juga mengenai pengambil-alihan keuntungan perusahaan oleh pemegang saham terbesar Dalam corporate governance framework, struktur kepemilikan yang berbeda mempunyai peran yang dominan dalam penentuan perilaku perusahaan mengenai keputusan keuangan dan pengambilan keputusan investasi. Parameter kunci dalam proses pengambilan keputusan perusahaan mungkin berada dalam situasi yang sulit ketika manajer dan pemilik mulai mengutamakan kepentingan dan tujuan pribadi yang akhirnya membahayakan profitabilitas perusahaan, masa depan dan kelangsungan hidup perusahaan. Saat ini ada perbedaan struktur corporate governance dalam hal struktur kepemilikannya yakni sistem kepemilikan tersebar dan struktur kepemilikan terkonsentrasi (Shah et al, 2012). Untuk itu dalam membuat kebijakan dan aturan tentang perilaku pengambilan risiko dan kinerja. perlu memperhatikan struktur kepemilikan perusahaan Kinerja perusahaan dipengaruhi oleh beberapa faktor, antara lain terkonsentrasi atau tidak terkonsentrasinya kepemilikan, manipulasi laba, serta pengungkapan laporan keuangan.

Studi ini bertujuan untuk mengetahui keterkaitan antara corporate governance, risiko dan karakteristik perusahaan yang diterapkan dalam suatu perusahaan dengan kinerja keuangan perusahaan. Pelaksanaan corporate governance yang baik dan sesuai dengan peraturan yang berlaku akan membuat investor merespon secara positif terhadap kinerja perusahaan dan meningkatkan nilai pasar perusahaan.

Tingkat implementasi corporate governance dalam penelitian ini menggunakan ukuran yang dikembangkan oleh Indonesia Institute of Corporate Governnace (IICG). Pengukuran ini disebut Corporate Governance Perception Index (CGPI) yang berupa skor. CGPI menghasilkan laporan riset pemeringkatan Good Corporate Governance (GCG) yang bersifat umum dan khusus. Laporan CGPI merupakan penilaian GCG dari luar perusahaan yang memiliki obyektivitas dalam hasil pemeringkatannya.

\section{REVIEW LITERATUR DAN HIPOTESIS}

Pengaruh corporate governance perception index terhadap kinerja keuangan

\section{Corporate Governance Perception}

Index merupakan sebuah hasil riset yang dilakukan oleh The Indonesian Institute for Corporate Governance (IICG) bekerjasama dengan majalah SWA untuk mengukur tingkat corporate governance perusahaan berdasarkan peringkatnya (Rohman dan Utama, 2013). Keberhasilan mekanisme corporate governance tercermin dalam penerapan tata kelola perusahaan yang baik untuk meningkatkan kinerja keuangan. Seperti yang di contohkan oleh Jensen dan Meckling (1976) perusahaan dengan governance yang baik akan memiliki kinerja operasional yang lebih efisien. Manajer bekerja secara efektif dan efisien sehingga dapat menurunkan biaya modal dan mampu meminimalkan risiko. Hal ini dapat terlihat pada harapan aliran kas masa depan yang tinggi. Tindakan tersebut akan menghasilkan profitabilitas yang tinggi.

Shah et al., (2012) menyatakan bahwa semakin baik penerapan corporate governance akan semakin meningkatkan kinerja keuangan. Hasil penelitian Nuswandari (2009) menunjukkan bahwa variabel corporate governance perception index secara positif signifikan mempengaruhi kinerja operasi. Berdasarkan uraian di atas, maka dapat diajukan hipotesis sebagai berikut:

$\mathrm{H} 1$ : Corporate governance performance index berpengaruh terhadap kinerja keuangan.

\section{Pengaruh risiko (risk) terhadap kinerja keuangan}

Risiko menuntut beberapa keputusan manajemen yang memiliki akibat baik atau 
buruk. Hal ini terjadi karena kebanyakan proyek dan keputusan manajemen mengandung risiko. Itulah sebabnya mengapa para manajer harus mempertimbangkan pilihan-pilihan yang berbeda terhadap beberapa masalah kinerja keuangan dan memperhitungkan konsekuensi-konsekuensinya dengan cara memfokuskan diri pada risiko-risiko yang lebih nyata (Umar, 1998). Menurut Shah et al., (2012) koefisien risiko tidak berpengaruh terhadap kinerja tetapi mempunyai hubungan negatif, hal ini mengindikasikan bahwa risiko dari perusahaan memiliki hubungan terbalik dengan kinerja keuangan. Berdasarkan uraian tersebut dapat diuji hipotesis sebagai berikut:

$\mathrm{H} 2$ : Risiko berpengaruh terhadap kinerja keuangan.

\section{Pengaruh kepemilikan institusional terhadap kinerja keuangan}

Kepemilikan Institusional adalah saham perusahaan yang dimilki oleh institusi atau lembaga (perusahaan asuransi, bank, perusahaan investasi dan institusi lainnya). Kepemilikan institusional memilki kemampuan untuk mengendalikan pihak manajemen melalui proses monitoring secara efektif sehingga mengurangi tindakan manajemen melakukan manajemen laba (Ujiyanto dan Pramuka, 2007).

Menurut Shah et al., (2012) kepemilikan institusional dapat berpengaruh signifikan terhadap berbagai ukuran kinerja. Dengan kinerja keuangan yang dijalankan oleh manajemen, para investor mempunyai tingkat pengawasan yang cukup kecil (terbatas) terhadap perusahaan. Penelitian Hastuti (2005) menemukan bahwa stuktur kepemilikan tidak berpengaruh terhadap kinerja keuangan. Berdasarkan uraian tersebut, peneliti mengembangkan uji hipotesis sebagai berikut:

H3: Kepemilikan institusional berpengaruh terhadap kinerja keuangan

\section{Pengaruh kesempatan bertumbuh terhadap kinerja keuangan}

Pertumbuhan penjualan mencerminkan manifestasi keberhasilan investasi periode masa lalu dan dapat dijadikan sebagai prediksi pertumbuhan masa yang akan datang. Pertumbuhan penjualan juga merupakan indikator permintaan dan daya saing perusahaan dalam suatu industri. Laju pertumbuhan suatu perusahaan akan mempengaruhi kemampuan mempertahankan keuntungan dalam mendanai kesempatan-kesempatan pada masa yang akan datang (Barton et al., 1989). Menurut Nuswandari (2009) variabel kesempatan investasi tidak memiliki pengaruh terhadap kinerja. Sedangkan penelitian Darmawati et al., (2004) menemukan bahwa variabel kesempatan investasi tidak mempengaruhi kinerja perusahaan. Penelitian Shah et al., (2012) menunjukkan bahwa variabel kesempatan investasi mempunyai hubungan signifikan, artinya hubungan ini mengindikasikan bahwa kinerja yang lebih tinggi memberikan hasil keuangan yang baik. Oleh karena itu hipotesis yang diuji adalah:

H4: Kesempatan bertumbuh berpengaruh terhadap kinerja keuangan.

\section{Pengaruh ukuran perusahaan terhadap kinerja keuangan}

Ukuran perusahaan (size) menggambarkan besar kecilnya suatu perusahaan yang ditunjukkan oleh total aktiva, jumlah penjualan, rata-rata tingkat penjualan dan rata-rata total aktiva. Menurut Nuswandari (2009) variabel ukuran perusahaan memiliki pengaruh terhadap kinerja. Penelitian Darmawati et al., (2004) menjelaskan bahwa variabel ukuran perusahaan tidak mempengaruhi kinerja perusahaan. Penelitian Shah et al., (2012) menunjukkan bahwa variabel ukuran perusahaan mempunyai hubungan signifikan (positif) terhadap kinerja keuangan serta memberikan hasil keuangan yang baik. Tingkat signifikasi dari koefisien ukuran 
perusahaan menunjukkan bahwa perusahaan dengan prestasi (positif) di pasar akan mencapai kinerja yang lebih baik. Oleh karena itu hipotesis yang diuji adalah:

H5: Ukuran perusahaan berpengaruh terhadap kinerja keuangan.

\section{METODE PENELITIAN}

\section{Pemilihan Sampel dan Pengumpulan Data}

Populasi objek penelitian ini yaitu seluruh perusahaan yang terdaftar (go public) di Bursa Efek Indonesia (BEI) tahun 20062012. Sedangkan sampel dalam penelitian ini adalah perusahaan yang masuk di BEI dan terdaftar sebagai anggota pemeringkatan corporate governance perception index (CGPI) selama periode 2006-2012. Jumlah sampelnya sebanyak 86 perusahaan. Pengambilan sampel menggunakan metode purposive sampling, Sampel penelitian berupa pooled data. Adapun kriteria-kriteria yang digunakan dalam pemilihan sampel adalah:

a. Perusahaan yang mendapatkan skor dalam CGPI yang telah dilakukan oleh IICG selama periode tahun 2006-2012.

b. Perusahaan listing dalam BEI selama periode tahun 2006-2012.

c. Perusahaan memiliki data keuangan lengkap yang berkaitan dengan variabel penelitian selama periode tahun 2006-2012.

d. Perusahaan yang mengeluarkan laporan keuangan tahun 2012 .

\section{Definisi Operasional dan Pengukuran Variabel}

Penelitian ini akan menguji variabel dependen yaitu kinerja perusahaan yaitu return on equity (ROE) dan variabel independen yaitu CGPI, risiko, kepemilikan institusional, kesempatan bertumbuh, dan ukuran perusahaan.

Dalam penelitian ini variabel dependen adalah kinerja keuangan tiap perusahaan. Kinerja keuangan diukur dengan menggunakan ROE.
Return on equity yang mengukur seberapa banyak laba bersih yang dapat dihasilkan dari investasi para pemegang saham dalam persuahaan. Rasio yang rendah dapat diartikan bahwa manajemen kurang efisien sedangkan rasio yang tinggi dapat menunjukkan bahwa manajemen sangat efisien. Untuk menghitung return on equity digunakan rumus (Kusumawati dan Irawati, 2013)

$$
\mathbf{R O E}=\frac{\text { Laba bersih setelah pajak }}{\text { Total modal sendiri }}
$$

Dalam penelitian ini variabel independen (bebas) adalah tipe variabel yang menjelaskan atau mempengaruhi variabel yang lain (Indriatoro dan Supomo, 1999). Variabel independen yang diteliti dalam penelitian ini adalah CGPI, risiko, kepemilikan institusional, kesempatan bertumbuh, dan ukuran persusahaan.

\section{a. Corporate Governance Perception Index (CGPI)}

Corporate Governance Perception Index (CGPI) merupakan sebuah hasil riset yang dilakukan oleh Indonesia. The Indonesian Institute for Corporate Governance (IICG) bekerjasama dengan majalah SWA untuk mengukur tingkat Corporate Governance yang diterapkan di perusahaan Indonesia. Hasil dari riset oleh IICG index corporate governance perusahaan diurutkan berdasarkan peringkat. Pengukuran variabel CGPI berdasarkan jumlah nilai akhir dari setiap tahapan penilaian, dalam bentuk persentase (Rohman dan Utama, 2013).

\section{b. Risko (Risk)}

Risiko sering dikaitkan dengan deviasi/ penyimpangan dari outcome yang diterima dengan yang dieskpektasikan. Risiko yang besar akan memberikan informasi bagi investor untuk berhati-hati (cenderung menunggu) ketika kondisi pasar tidak stabil, sehingga menimbulkan turunnya minat investor untuk menanamkan 
modal. Dengan menurunnya minat investor untuk berinvestasi menyebabkan kinerja perusahaan terhambat karena kurangnya modal untuk menjalankan operasi perusahaan. Perusahaan dengan risiko tinggi akan memberikan insentif yang besar kepada para manajer yang mengelola perusahaan tersebut, agar pengelolaan perusahaan dilakukan dengan sebaik-baiknya sehingga dapat meningkatkan kinerja keuangan. Dalam penelitian ini risiko keuangan diukur dengan menggunakan rumus (John et al., 2007):

$$
\sigma_{\mathrm{i}, \mathrm{c}}=\sqrt{\frac{1}{n-1} \sum_{\mathrm{t}=1}^{\mathrm{T}}\left(\frac{B T}{\mathrm{~A}}-\frac{1}{\mathrm{n}} \sum_{\mathrm{t}=1}^{\mathrm{T}} \frac{E B T}{\mathrm{~A}}\right)^{2}}
$$

Keterangan:

EBT : Profit(loss) before taxes (laba sebelum pajak)

A : Total Aset

\section{c. Kepemilikan Institusional}

Kepemilikan institusional adalah kepemilikan saham oleh institusi. Kepemilikan institusional yang tinggi akan menimbulkan usaha pengawasan yang lebih besar oleh pihak institusional. Sehingga dapat menghalangi perilaku oportunistik dari para manajer perusahaan (Kusumawardhani, 2012).

Kepemilikan saham diukur dengan proporsi saham yang dimiliki oleh institusional pada akhir tahun dibandingkan dengan jumlah saham yang beredar pada perusahaan tersebut (Kusumawardhani, 2012).

$$
I N S T=\frac{\text { jumlah saham yang di miliki oleh institusi }}{\text { jumlah saham beredar }}
$$

Dalam penelitian ini kepemilikan institusi didapat langsung dari Indonesian Capital Market Direktori (ICMD).

\section{d. Kesempatan Bertumbuh (Growth Sales)}

Pertumbuhan penjualan mencerminkan manifestasi keberhasilan investasi periode lalu dan dapat dijadikan sebagai prediksi pertumbuhan masa yang akan datang. Pertumbuhan penjualan juga merupakan indikator permintaan dan daya saing perusahaan dalam suatu industri. Laju pertumbuhan suatu perusahaan akan mempengaruhi kemampuan mempertahankan keuntungan dalam mendanai kesempatankesempatan pada masa yang akan datang (Barton et al., 1989).

Perusahaan yang memiliki kesempatan bertumbuh tinggi pada umumnya membutuhkan dana eksternal untuk melakukan ekspansi, sehingga mendorong perusahaan untuk melakukan perbaikan dalam penerapan good corporate governance. Dalam penelitian ini kesempatan bertumbuh diukur dengan pertumbuhan penjualan (growth sales) sesuai dengan penelitian Shah et al., (2012) yaitu:

$$
\text { Growth Sales }=\frac{\mathrm{S}_{\mathrm{t}}-\mathrm{S}_{\mathrm{t}-1}}{\mathrm{~S}_{\mathrm{t}-1}}
$$

Keterangan :

$\mathrm{S}_{\mathrm{t}}$ : Penjualan tahun ke-t

$\mathrm{S}_{\mathrm{t}-1}$ : Penjualan tahun ke-t-1

\section{e. Ukuran Perusahaan (size)}

Besar kecilnya perusahaan dapat dilihat dari total aktiva (asset) dan total penjualan (net sales) yang dimiliki oleh perusahaan. Beberapa penelitian menggunakan ukuran aktiva sebagai ukuran perusahaan (Kusumawardhani, 2012). Rohman dan Utama (2013) menyatakan bahwa perusahaan yang memilik aktiva yang besar menunjukkan perusahaan tersebut sudah mencapai tingkat kemapanan. Ketika suatu perusahaan dinilai mempunyai aktiva yang besar akan memunculkan pandangan bagi investor bahwa berinvestasi di perusahaan dengan tingkat aktiva besar memiliki risiko yang lebih kecil sehingga banyak investor yang ingin berinvestasi di perusahaan tersebut. Dalam penelitian ini variabel ukuran perusahaan (size) diukur dengan menggunakan logaritma natural (LN) dari total 
aset (Shah et al., 2012). Hal ini dikarenakan besarnya masing-masing total aset berbeda antara masing-masing perusahaan, bahkan mempunyai selisih yang besar sehingga dapat menyebabkan nilai yang ekstrim (Budiyanti dan Ifada, 2012). Sehingga menurut Shah et al., (2012) dapat dirumuskan sebagai berikut :

\section{Size $=$ Ln Total Assets}

\section{Jenis Data dan Sumber Data}

Ada dua jenis data yang digunakan dalam penelitian ini, yaitu data kualitatif dan data kuantitatif. Data kualitatif diambil dari buku, jurnal, makalah, penelitian terdahulu, dan situs internet yang berhubungan dengan tema penelitian ini. Sedangkan data kuantitatif berupa angka-angka yang terdapat pada ICMD yang didapat di Pojok Bursa Efek Indonesia (BEI) Fakultas Ekonomi dan Bisnis Universitas Muhammadiyah Surakarta, annual report untuk data tahun 2012 yang diperoleh dari http://www. idx.co.id/ dan laporan Corporate Governance Perception Index (CGPI) tahun 2006-2012 yang diperoleh dari http://www.mitrariset.com/.

\section{Metode Analisis Data}

Pengujian hipotesis mengenai pengaruh CGPI, risiko (risk), kepemilikan intitusional (INST), kesempatan bertumbuh (growth sales), dan ukuran perusahaan (size) terhadap kinerja keuangan dalam penelitian ini menggunakan analisis regresi berganda. Adapun model regresinya adalah sebagai berikut:

$\mathrm{ROE}=\alpha+\beta_{1} \mathrm{CGPI}+\beta_{2} \mathrm{RISK}+\beta_{3} \mathrm{INST}+\beta_{4} \mathrm{GS}$ $+\beta_{5} \mathrm{SIZE}+\mathrm{e}$

\section{HASIL PENELITIAN DAN PEMBAHASAN}

Tabel 1

Statistik Deskriptif Data

\begin{tabular}{|c|c|c|c|c|c|}
\hline & $\mathbf{N}$ & MIN & MAX & MEAN & SD \\
\hline ROE & 86 & 0.0013 & 0.5103 & 0.195 & 0.1029 \\
\hline CGPI & 86 & 64.14 & 91.91 & 80.65 & 6.5033 \\
\hline INST & 86 & 0.0526 & 0.9912 & 0.655 & 0.1879 \\
\hline RISK & 86 & 0.00147 & 0.250812 & 0.05174 & 0.0534 \\
\hline GS & 86 & -0.3441 & 12.6919 & 0.327 & 1.3683 \\
\hline SIZE & 86 & 12.00606 & 20.2701 & 17.149 & 1.8435 \\
\hline
\end{tabular}

Sumber : hasil olah data

Kinerja keauangan yang diukur menggunakan return on equty (ROE) yang merupakan tingkat pengembalian atas penggunaan modal perusahaan. Berdasarkan statistik deskriptif dapat diketahui dari 86 perusahaan go public yang memperoleh skor dalam pemeringkatan CGPI di Bursa Efek Indonesia mempunyai ROE terendah yaitu $0,13 \%$; sementara ROE tertinggi adalah $51,03 \%$ dan dengan standar deviasi 10,29194\%. Adapun rerata ROE perusahaan go public yang memperoleh skor dalam pemeringkatan CGPI di Bursa Efek Indonesia tahun 2006-2012 adalah $19,5679 \%$.

Berdasarkan hasil perhitungan statistik deskriptif dapat diketahui Corporate Governance Perception Index (CGPI) memiliki nilai rerata $80,6583 \%$, hal ini menunjukkan bahwa secara rerata perusahaan mempunyai predikat terpercaya. Nilai CGPI terendah $64,14 \%$ dan nilai CGPI tertinggi 91,91\%.

Berdasarkan hasil perhitungan statistik deskriptif dapat diketahui kepemilikan institusional (INST) menunjukkan seberapa besar saham perusahaan dimiliki oleh institusi. Pada tabel di atas nilai rerata INST 65,5683\%,. Nilai INST terendah 5,26\% dan nilai tertinggi 99,12\%.

Berdasarkan hasil perhitungan statistik deskriptif tentang risiko (RISK) menunjukkan jika kinerja keuangan suatu perusahaan semakin baik maka mempunyai risiko yang besar pula untuk menjalankan perusahaan. RISK dalam penelitian ini memiliki rerata 5,174001\%, 
sedangkan nilai tertingginya yaitu $25,0812 \%$ dan terendahnya $0,1471 \%$.

Berdasarkan hasil perhitungan statistik deskriptif menunjukkan bahwa kesempatan bertumbuh yang diukur dengan tingkat pertumbuhan penjualan (Growth Sales/ GS) memiliki nilai rerata $32,769103 \%$ Nilai tertinggi dari Growth Sales 1269,1972\% dan nilai terendah $-34,4169 \%$.

Berdasarkan hasil perhitungan statistik deskriptifmenunjukkan bahwa ukuran perusahaan (SIZE) mempunyai rerata $17,14942336 \%$, dan nilai terendah $12,006060 \%$ sedangkan nilai tertinggi $20,270109 \%$.

\section{Uji Asumsi Klasik}

Dalam penelitian ini uji normalitas dilakukan dengan uji One KolmogorovSmirnov hasilnya menunjukkan bahwa nilai signifikansi atau probabilitas dari model memiliki nilai sebesar $0,959>0,05(\alpha)$ maka data berdistribusi normal. Untuk mendeteksi ada tidaknya multikolinearitas dalam model regresi berganda dapat dilihat dari nilai tolerance dan Variance Inflation factor (VIF ). Hasil uji dari multikolinearitas menunjukkan bahwa seluruh variabel independen memiliki nilai VIF $<10$ dan nilai tolerance $>0.1$ sehingga dapat disimpulkan bahwa model tidak terjadi multikolinearitas. Sedangkan Pendeteksian adanya heteroskedasti sitas menggunakan uji Rank-Spearman. Hasil uji Rank Spearman menunjukkan nilai signifikan $>0.05$ maka dapat dikatakan bahwa model regresi tersebut tidak terjadi heteroskedastisitas. Hasil uji menunjukkan bahwa tidak terjadi heteroskedastisitas pada model. Hal ini terlihat dari probabilitas signifikan $>0.05$. Dan dalam mendeteksi adanya autokorelasi digunakan uji Durbin Watson. Berdasarkan hasil uji diperoleh nilai Durbin-Watson 1,978 angka ini berada pada dU $<$ DW $<4$-dU yaitu 1,7478 $<1,978<2,2522$ ini artinya bahwa dalam model tersebut tidak terdapat autokorelasi. (Ghozali, 2012)

\section{Uji Hipotesis (Uji t)}

\section{Tabel 2}

Hasil Uji Regresi Linear Berganda

\begin{tabular}{|l|c|c|c|l|}
\hline Variabel & Koef. Regr & $\mathbf{t}_{\text {hitung }}$ & Sig & Keterangan \\
\hline Konstanta & $-0,245$ & $-1,906$ & 0.060 & \\
\hline CGPI & 0,003 & 2,003 & 0,049 & Signifikan \\
\hline INST & 0,040 & 0,786 & 0,434 & Tidak Signifikan \\
\hline RISK & 0,915 & 4,926 & 0,000 & Signifikan \\
\hline GS & 0,020 & 2,843 & 0,006 & Signifikan \\
\hline SIZE & 0,005 & 0,796 & 0,444 & TIdak Signifikan \\
\hline F & 8,305 & & & \\
\hline $\mathrm{R}^{2}$ & 0,342 & & & \\
\hline Adj R & 0,301 & & & \\
\hline
\end{tabular}

Sumber : hasil olah data

\section{Pengaruh Corporate Governance Perception Index terhadap Kinerja Keuangan}

Berdasarkan hasil pengujian hipotesis pertama menunjukkan hasil bahwa corporate governance perception index (CGPI) mempunyai pengaruh signifikan terhadap kinerja keuangan yang diukur dengan return on equity (ROE). Hasil uji $t$ memperoleh nilai $t_{\text {hitung }}>\mathrm{t}_{\text {tabel }}(2,003>$ 1,990 ) dengan nilai signifikasi $0,049<0,05$; besar nilai koefisien regresi untuk variabel corporate governance perception index (CGPI) adalah 0,003 dengan parameter positif maka $\mathbf{H}_{\mathbf{1}}$ diterima. Berdasarkan parameter dari koefisien regresi dapat dijelaskan bahwa jika index corporate governance perusahaan naik maka akan berdampak terhadap naiknya kinerja keuangan. Dalam hasil penelitian Jensen dan Meckling (1976) menyatakan bahwa perusahaan dengan governance yang baik akan memiliki kinerja operasional yang lebih efisien. Manajer bekerja secara efektif dan efisien sehingga dapat menurunkan biaya modal dan mampu meminimalkan risiko. Hal ini terlihat pada espektasi aliran kas masa depan yang meningkat. Tindakan tersebut akan menghasilkan profitabilitas yang meningkat pula sehingga memberi sinyal positif meningkatkan kinerja keuangan.

Penelitian ini mendukung penelitian yang dilakukan oleh Shah et al., (2012), Nuswandari (2009), dan Darmawati et al., (2004) mendukung 
penelitian ini karena corporate governance perception index (CGPI) mempengaruhi posiitf terhadap kinerja keuangan, sedangkan menurut Meythi dan Devita (2011) yang menyatakan bahwa corporate governance perception index CGPI tidak mempengaruhi kinerja perusahaan.

\section{Pengaruh Risiko terhadap Kinerja Keuangan}

Berdasarkan hasil pengujian hipotesis kedua mendapatkan hasil bahwa risiko mempunyai pengaruh yang signifikan terhadap kinerja keuangan yang diukur dengan return on equity (ROE). Hasil uji $t$ memperoleh nilai $t_{\text {hitung }}>t_{\text {tabel }}$ $(4,929>1,990)$ dengan nilai signifikasi sebesar $0.000<0,05$; besar nilai koefisien regresi untuk variabel risiko adalah 0,915 dengan parameter positif maka $\mathbf{H}_{2}$ diterima. Berdasarkan parameter koefisien regresi tersebut dapat dijelaskan bahwa semakin besar risiko yang ada didalam perusahaan maka akan meningkatkan return perusahaan, hal ini mengindikasikan bahwa kinerja keuangan juga mengalami peningkatan. Penelitian ini didukung oleh penelitian Shah et al., (2012) yang menyatakan bahwa risiko berpengaruh terhadap kinerja keuangan.

\section{Pengaruh Kepemilikan Institusional terhadap Kinerja Keuangan}

Berdasarkan pengujian hipotesis ketiga menunjukkan hasil bahwa kepemilikan institusional mempunyai pengaruh tidak signifikan terhadap kinerja keuangan yang diukur dengan return on equity (ROE). Hasil uji $\mathrm{t}$ memperoleh nilai $\mathrm{t}_{\text {hitung }}<\mathrm{t}_{\text {tabel }}(0,786<1,990)$ dengan nilai signifikansi lebih besar dari alphanya $(0,434>0,05)$; besar nilai koefisien regresi untuk variabel kepemilikan institusional adalah 0,040 dengan parameter positif maka $\mathbf{H}_{3}$ ditolak. Penelitian ini didukung oleh penelitian Hapsoro (2008) yang menyatakan bahwa kepemilikan institusi mempunyai pengaruh tidak signifikan terhadap kinerja keuangan perusahaan, sedangkan penelitian ini tidak didukung oleh penelitian Shah et al., (2012) yang menyatakan bahwa kepemilikan intitusi berpengaruh signifikan terhadap kinerja keuangan perusahaan. Dengan adanya kepemilikan intitusional yang lemah mengakibatkan manajemen bertindak dan bersikap opportunistik, sehingga mengabaikan kepentingan pemilik, yang secara tidak langsung menurunkan kinerja perusahaan (Ujiyanto dan Pramuka, 2007).

\section{Pengaruh Kesempatan Bertumbuh Ter- hadap Kinerja Keuangan}

Berdasarkan hasil pengujian hipotesis keempat mendapatkan hasil bahwa kesempatan bertumbuh mempunyai pengaruh signifikan terhadap kinerja keuangan yang diukur dengan return on equity (ROE). Hasil uji t memperoleh nilai $\mathrm{t}_{\text {hitung }}>\mathrm{t}_{\text {tabel }}(2,843>1,990$ dengan nilai signifikasi sebesar $0,016<0,05$ ); besar nilai koefisien regresi untuk variabel risiko adalah 0,020 dengan parameter positif maka $\mathbf{H}_{4}$ diterima. Penelitian ini didukung oleh penelitian Shah et al., (2012) yang menyatakan bahwa kesempatan bertumbuh berpengaruh signifikan terhadap kinerja keuangan, sedangkan penelitian ini tidak sejalan dengan penelitian Nuswandari (2009) dan Darmawati et al., (2004) yang menyatakan bahwa kesempatan bertumbuh tidak mempunyai pengaruh signifikan terhadap kinerja perusahaan. Berdasarkan parameter dari koefisien regresi dapat dijelaskan bahwa jika pertumbuhan penjualan dari tahun ke tahun mengalami kenaikan maka akan berdampak terhadap naiknya kinerja keuangan. Perusahaan dengan tingkat penjualan yang tinggi secara tidak langsung memiliki laba yang tinggi pula namun harus diimbangi dengan rendahnya beban opersional perusahaan.

\section{Ukuran Perusahaan dengan Kinerja}

Berdasarkan hasil pengujian hipotesis kelima mendapatkan hasil bahwa ukuran perusahaan mempunyai berpengaruh tidak sig- 
nifikan terhadap kinerja keuangan yang diukur dengan return on equity (ROE). Hasil uji $\mathrm{t}$ memperoleh nilai $\mathrm{t}_{\text {hitung }}<\mathrm{t}_{\text {tabel }}(0,769<1,990)$ dengan nilai signifikasi sebesar $0,444>0,05$; besar nilai koefisien regresi untuk variabel ukuran perusahaan adalah 0,05 dengan parameter positif maka $\mathbf{H}_{5}$ ditolak. Hal ini menunjukkan bahwa ukuran perusahaan bukan jaminan bahwa perusahaan memiliki kinerja keuangan yang baik (Fachrudin, 2011). Penelitian ini didukung oleh Darmawati et al., (2004) yang menyatakan bahwa ukuran perusahaan tidak mempunyai pengaruh terhadap kinerja perusahaan, sedangkan penelitian ini tidak sejalan dengan penelitian yang dilakukan oleh Shah et al., (2012), dan Nuswandari (2009) yang menyatakan bahwa ukuran perusahaan berpengaruh positif terhadap kinerja keuangan.

\section{KESIMPULAN DAN SARAN}

Isu sentral dalam penelitian ini adalah pengujian pengaruh corporate governance perception index, risiko, kepemilikan institusional, kesempatan bertumbuh, dan ukuran perusahaan terhadap kinerja keuangan yang diukur dengan Return On Equity (ROE). Variabel dependen yang berpengaruh signifikan terhadap kinerja keuangan adalah corporate governance perception index, risiko dan kesempatan bertumbuh dengan arah positif. Sedangkan kesempatan bertumbuh dan ukuran perusahaan tidak berpengaruh terhadap kinerja keuangan.

Sejumlah keterbatasan dalam penelitian ini adalah pertama, pengukuran kinerja perusahaan menggunakan return on equity (ROE) tanpa membedakan jenis industrinya sehingga memungkinkan daya banding return on equity (ROE) terjadi bias industri. Untuk penelitian selanjutnya diharapkan dalam mengukur kinerja keuangan menggunakan return on equity (ROE) dengan membedakan berdasarkan jenis industrinya. Kedua, risiko yang digunakan dalam peneli- tian ini hanya sebatas risiko internal perusahaan sehingga belum memberikan tingkat risiko yang berasal dari luar perusahaan. Dalam penelitian selanjutnya diharapkan untuk menggunakan risiko pasar yang dapat mengetahui risiko yang berasal dari luar perusahaan. Ketiga, penelitian ini tidak dibedakan berdasarkan jenis industri, jadi memungkinkan adanya bias industri. Dalam penelitian berikutnya diharapkan membedakan jenis industri, agar tidak terjadi bias industri.

\section{DAFTAR PUSTAKA}

Barton, Sidney.L; Ned.C Hill; Srinivasav Sundaran.1989.An Empirical Test of Stakeholder Theory Prediction of Capital Structure. Financial Management (Spring 1989).

Budiyanti dan Luluk M.Ifada. 2012. Karakteristik Perusahaan Dan Kualitas Implementasi Corporate Governance. EKOBIS Vol.14. No.2.

Darmawati, Deni., Khomsiyah, dan Rika Gelar Rahayu. 2004. Hubungan Corporate Governance dan Kinerja Perusahaan. Simposium Nasional Akuntansi VII. Denpasar-Bali, 2-3 Desember 2004.

Fachrudin, Khaira Amalia. 2011. Analisis Pengaruh Struktur Modal, Ukuran Perusahaan, dan Agency Cost Terhadap Kinerja Perusahaan. (online) Jurnal Akuntansi dan Keuangan, Vol. 13, No. 1, Mei 2011:37-46

Ghozali, Imam. 2012. Aplikasi Analisis Multivariate dengan Program IBM SPSS 20 ed 6. Semarang: Badan Penerbitan Universitas Diponegoro.

Hastuti, Theresia Dwi. 2005. Hubungan Antara Good Corporate Governance dan Struktur Kepemilikan dengan Kinerja Keuangan (Sudi Kasus pada Perusahaan yang listing di Bursa Efek Jakarta). 
Simposium Nasional Akuntansi VIII. Solo, 15-16 September 2005.

Hapsoro, Dody. 2008 .Pengaruh Mekanisme Corporate Governance Terhadap Kinerja Perusahaan: Studi Empiris Di Pasar Modal Indonesia. Jurnal Akuntansi dan Manajemen Vol. 19, No. 3, Desember 2008.

Indriantoro, Nur dan Bambang Supomo.2002. Metodologi Penelitian Bisnis Untuk Akuntansi Dan Manajemen. Yogyakarta: BPFE.

Jensen, M., C., dan Meckling, W., H. 1976. Theory of the Firm: Managerial Behavior, Agency Cost, and Capital Structure. Journal of Financial Economics, 3:305.

John, K., Litov, L., dan Yeung, B. 2008. Corporate Governance and Risk-Taking. Journal of Finance, 63:1979.

Kusumawati, Eni dan Zulfa Irawati. 2013. Manajemen Keuangan. Surakarta: UMS

Kusumawardhani, Indra. 2012. Pengaruh Corporate Governance, Struktur Kepemilikan, dan Ukuran Perusahaan Terhadap Manajemen Laba. Jurnal Akuntansi dan Sistem Informasi Teknologi.Vol.9.No.1.

Meythi dan Lusiyana Devita. 2011. Pengaruh Penerapan Good Corporate Governance (GCG) Terhadap Kinerja Keuangan Perusahaan: Studi Empirik Pada Perusahaan Go Public Yang Termasuk Kelompok Sepuluh Besar Menurut Corporate Governance Perception Index (CGPI) Di Bursa Efek Indonesia. Dialogia Iuridicia, November 2011, Vol.3 No.1

Nuswandari, Cahyani. 2009. Pengaruh Corporate
Governance Perception Index Terhadap Kinerja Perusahaan Pada Persuahaan Yang Terdaftar Di Bursa Efek Jakarta. Jurnal Bisnis dan Ekonomi (JBE), September 2009, Hal. 79-84 Vol. 16, No. 2 (ISSN: 1412-3126).

Rohman, Abdul dan Tito Albi Utama. 2013. Pengaruh Corporate Governance Perception Index, Profitabilitas, Leverage, dan Ukuran Perusahaan Terhadap Nilai Saham. Diponegoro Journal of Accounting. Vol.2. No.2. hal 1-9.

Shah, Abid Ali.,Rehana Kouser.,Muhammad Aamir.,Ch.Mazhar Hussain. 2012. The Impact of The Corporate Governance and The Ownership Structure on The Firm's Financial Performance and its Risk Taking Behavior._International Research Journal of Finance and Economics. ISSN 1450-2887 Issue 93.

Ujiyantho, Muh. Arief dan Bambang Agus Pramuka. 2007. Mekanisme Corporate Governance, Manajemen Laba dan Kinerja Keuangan (Studi Pada Perusahaan go publik Sektor Manufaktur). Simposium Nasional Akuntansi X. Makasar 26-28 Juli 2007.

Umar, Husein. 1998. Manajemen Risiko Bisnis (Pendekatan Finansial dan Non Finansial). Jakarta: PT Gramedia.

http://iicg.org/v25/ diakses pada tanggal 7 November 2013 pukul 17.00

http://www.mitrariset.com/ diakses pada tanggal 16 Juli 2013 pukul 10.00

www.idx.com diakses pada tanggal 15 Oktober 2013 pukul 13.00 